\title{
The Comparison and Analysis of Two Extraction Methods for Polysaccharides in Psidium guajava L. Fruits
}

\author{
Michael Antony Samy Amutha Gnana Arasi ${ }^{1 *}$, Manchineela Gopal Rao², Janardanan Bagyalakshmi \\ ${ }^{1}$ Assistant Professor, Department of Pharmaceutics, College of Pharmacy, Sri Ramakrishna Institute of Paramedical Sciences, \\ Coimbatore, Tamil Nadu, INDIA. \\ ${ }^{2}$ Vice Principal and Head of the Department of Pharmaceutics, College of Pharmacy, Sri Ramakrishna Institute of Paramedical \\ Sciences, Coimbatore, Tamil Nadu, INDIA. \\ ${ }^{3}$ Associate Professor, Department of Pharmaceutics, College of Pharmacy, Sri Ramakrishna Institute of Paramedical Sciences, \\ Coimbatore, Tamil Nadu, INDIA.
}

\begin{abstract}
Introduction: Fruit polysaccharides, essential health factors in foods, are widely present in edible fruits. Several methods for isolation of polysaccharide are available. Microwave Assisted Extraction (MAE) method is extensively used for separation of polysaccharides. Only little information is available about Psidium guajava L. Fruit Polysaccharide (PFP) and its extraction methods. Objective: In this study, two extraction methods of polysaccharides in Psidium guajava L. fruit were compared and the best method was ascertained. Methods: Psidium guajava L. polysaccharides were extracted using water extraction with conventional heating and microwave assisted extraction method. The factors that influenced water extraction with conventional heating included temperature, water to plant material ratio, extraction time and solvent to liquid ratio. The factors that influenced MAE of polysaccharides extraction included microwave power, irradiation time and solvent to liquid ratio. Yield is considered as the independent variable in both the methods. Results: By the result of the single factorial method and orthogonal experiments, the optimal extracting conditions were selected and then the best extraction method was ascertained. The optimum extraction conditions of water extraction with conventional heating include temperature $90^{\circ} \mathrm{C}$, water to plant material ratio $1: 1$, extraction time 1 hour $30 \mathrm{~min}$ and solvent to liquid ratio $2: 1$. The results showed that the extraction yield of microwave method was higher under the optimal conditions of irradiation time 20 min, microwave power $200 \mathrm{~W}$ and $3: 1$ solvent to liquid ratio than the water extraction with conventional heating.
\end{abstract}

Key words: Guava, Polysaccharides, Extraction, Optimization, Taguchi orthogonal, Comparison.

\section{INTRODUCTION}

Psidium guajava L or common guava is a tropical/subtropical fruit plant of the world. It belongs to family Myrtaceae and originated from tropical America. ${ }^{1}$ Guava contains wide-ranging of phytochemical including polysaccharides. ${ }^{2,3}$ In addition, ascorbic acid, pectin and other mineral contents are more in guava fruits in comparison with other fruits. A major component of guava fruit is pectin, which is an anionic polysaccharide mainly composed of partially esterified $D$-galacturonic acid monomers linked by $\alpha-(1-4)$ bonds. $^{4}$

Fruit polysaccharides, essential health factors in foods, are extensively present in edible fruits. In recent years, a close understand-
Submission Date : 26-04-2016 Revision Date : 20-06-2016 Accepted Date : 16-07-2016

DOI: 10.5530/ijper.50.3.32 Correspondence: M. A. Amutha Gnana Arasi, College of Pharmacy, Sri Ramakrishna Institute of Paramedical Sciences, Sarojini Naidu Road, Coimbatore, Tamil Nadu, INDIA.

Phone no: 91-9791163755 E-mail: amutha.jr@gmail. com

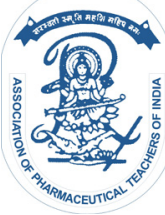

www.ijper.org 
ing of natural polysaccharides has promoted studies that deal with isolation and physical, chemical and structural characterization of polysaccharides ${ }^{5-8}$ Only very few information is available about Psidium guajava L. Fruit Polysaccharide (PFP) and its extraction methods.

Most commonly used extraction methods for isolation of polysaccharide are water extraction, alcohol precipitation, acid or alkali extraction, ultra sound assisted, enzyme hydrolysis and Microwave Assisted Extraction (MAE). As the polysaccharides have lower solubility in high concentration of alcohol or ether, it can be precipitated out when alcohol or ether added to an aqueous solution of polysaccharide. ${ }^{10}$ Water extraction and alcohol precipitation are inexpensive and easy method but in contrast, they have higher extraction temperature and slow extraction rate. Ultrasound assisted extraction results tissue deformation and rupture, and release contents; in order to promote the dissolution of the active ingredients within the cell, but the high power will cause harm to the structure of polysaccharide and the material out of the cells induce the difficulty of separation. ${ }^{11}$ Alkali, acid extraction method is suitable for selected polysaccharides. ${ }^{12}$ Enzymatic method is expensive one. ${ }^{13}$ Nowadays, Microwave Assisted Extraction method (MAE) is extensively used for separation of polysaccharides. MAE is easy, efficient method with low extraction time.

The present study aims to perform a comparative analysis of water extraction method with conventional heating and MAE of polysaccharides from Psidium guajava L. fruits.

\section{MATERIALS AND METHODS}

Fresh Psidium guajava L fruits were purchased from nearby garden in Coimbatore. The authentication of the plant was obtained from the Botanical Survey of India situated in the Tamil Nadu Agricultural University located in Coimbatore. All the other chemicals used in the study were of laboratory grade.

\section{Water extraction of polysaccharides with conventional heating from Psidium guajava L. fruit}

Half ripened fresh Psidium guajava L. fruits were cut, the skin and seeds were cleaned and grounded, exact quantity immersed in water for 2 hours. The $\mathrm{pH}$ of the solution was adjusted to $\mathrm{pH} 4.5$ with tartaric acid solution (10\%) and boiled under reflux for 1 hour with occasional stirring. After cooling excess fragments were removed by centrifugation process. The mucilage solution was precipitated with acetone. Extractions were performed at different conditions using single factor experiments.
Then the polysaccharides thus obtained are filtered, air dried and dried in a hot air oven at a temperature not exceeding $50^{\circ} \mathrm{C}$. The yield is calculated by the following formula (Equation 1).

Yield $(\%)=$ (Weight of the polysaccharide obtained / Weight of the fruit material) $\times 100 \quad$ Equation 1 .

The factors that influenced water extraction with conventional heating included temperature, water to plant material ratio, extraction time and solvent to liquid ratio. In single factor experiments, the Psidium guajava L. fruit polysaccharide was extracted using various temperature $\left(70^{\circ} \mathrm{C}, 80^{\circ} \mathrm{C}, 90^{\circ} \mathrm{C}\right)$, water to plant material ratio $(1: 1$, 2:1, 3:1), extraction time (30 min, $1 \mathrm{hr}, 1 \mathrm{hr} 30 \mathrm{~min}$ ) and solvent to liquid ratio $(1: 1,2: 1,3: 1)$.

Pectin from the Psidium guajava $\mathrm{L}$ fruits can be obtained from the same method explained above except that about 7-10 grams of citric acid or tartaric acid was added to fruit material and then it was subjected to heating then extracted with suitable solvent. ${ }^{14}$

Orthogonal experiment: Taguchi method is a new statistical method used to improve the quality of the manufactured goods. This method uses a special set of arrays known as orthogonal arrays. These standard arrays stipulate the way of conducting minimal number of experiments which could give the full information of all the factors that affect the performance parameter. This array assumes that there is no interaction between any two factors. ${ }^{15}$ The L9 orthogonal array was adopted for the present study. The response variable in the data analysis is not the raw response or quality characteristic; it is the signal-to-noise ratio. ${ }^{16}$

The factors that influenced water soluble polysaccharides extraction included temperature, water to plant material ratio, extraction time and solvent to liquid ratio. In single factor experiments, the PFP was extracted using various temperature $\left(70^{\circ} \mathrm{C}, 80^{\circ} \mathrm{C}, 90^{\circ} \mathrm{C}\right)$, water to plant material ratio $(1: 1,2: 1,3: 1)$, extraction time $(30 \mathrm{~min}, 1 \mathrm{hr}, 1 \mathrm{hr}$ $30 \mathrm{~min})$ and solvent to liquid ratio $(1: 1,2: 1,3: 1)$ as shown in Table 1. Signal to noise ratio can be calculated by the following formula. ${ }^{17}$

$\mathrm{SN}_{\mathrm{i}}=10 \log \left(\mathrm{Y}_{\mathrm{i}}^{2} / \mathrm{S}_{\mathrm{i}}^{2}\right)$ (Equation 2).

Where SNi- Signal to noise ratio of the experimental data

$\mathrm{Y}_{\mathrm{i}}$ - Mean of the three sets of experimental data

$\mathrm{S}_{\mathrm{i}}$-Standard deviation of the experimental data

\section{MAE of Psidium gujava L fruit polysaccahride(PFP)}

Except the boiling with reflux for 1 hour, the method is same as described above in water extraction method with conventional heating. In microwave assisted extrac- 


\section{Table 1: L9 $\left(3^{4}\right)$ Orthogonal table of water extraction of Psidium gujava L fruit} polysaccahride(PFP) with conventional heating

\begin{tabular}{|c|c|c|c|c|}
\hline \multicolumn{5}{|c|}{ Factors } \\
\hline Level & $\begin{array}{c}\text { A } \\
\text { Temperature }\end{array}$ & $\begin{array}{c}\text { B } \\
\text { Water to plant } \\
\text { material ratio }\end{array}$ & Extraction time & $\begin{array}{c}\text { D } \\
\text { Solvent to liquid } \\
\text { ratio }\end{array}$ \\
\hline 1 & $70^{\circ} \mathrm{C}$ & $1: 1$ & $30 \mathrm{~min}$ & $1: 1$ \\
\hline 2 & $80^{\circ} \mathrm{C}$ & $2: 1$ & $1 \mathrm{hr}$ & $2: 1$ \\
\hline 3 & $90^{\circ} \mathrm{C}$ & $3: 1$ & $1 \mathrm{hr} 30 \mathrm{~min}$ & $3: 1$ \\
\hline
\end{tabular}

(Source: Original).

\begin{tabular}{|c|c|c|c|}
\hline \multicolumn{4}{|c|}{ Factors } \\
\hline Level & $\begin{array}{c}\text { A } \\
\text { Microwave Power }\end{array}$ & $\begin{array}{c}\text { B } \\
\text { Irradiation time }\end{array}$ & $\begin{array}{c}\text { C } \\
\text { Solvent to Liquid ratio }\end{array}$ \\
\hline 1 & $100 \mathrm{~W}$ & $10 \mathrm{~min}$ & $1: 1$ \\
\hline 2 & $200 \mathrm{~W}$ & $20 \mathrm{~min}$ & $2: 1$ \\
\hline 3 & $300 \mathrm{~W}$ & $30 \mathrm{~min}$ & $3: 1$ \\
\hline
\end{tabular}

\section{Table: 3 L9 $\left(3^{4}\right)$ Orthogonal experiment results of water extraction method with conventional heating}

\begin{tabular}{|c|c|c|c|c|c|c|c|c|c|c|}
\hline \multirow[b]{2}{*}{ S.no } & \multirow[b]{2}{*}{$\begin{array}{c}\text { Temperature } \\
\text { (A) }\end{array}$} & \multirow{2}{*}{$\begin{array}{c}\text { Water to } \\
\text { plant material } \\
\text { ratio(B) }\end{array}$} & \multirow[b]{2}{*}{$\begin{array}{l}\text { Extraction } \\
\text { Time (C) }\end{array}$} & \multirow{2}{*}{$\begin{array}{l}\text { Solvent } \\
\text { to Liquid } \\
\text { ratio (D) }\end{array}$} & \multicolumn{3}{|c|}{ Extraction Yield (\%) } & \multirow[t]{2}{*}{ Mean } & \multirow[b]{2}{*}{ S.D } & \multirow[t]{2}{*}{$\mathrm{SNi}$} \\
\hline & & & & & Trial 1 & Trial 2 & Trial 3 & & & \\
\hline 1 & $\mathrm{~A} 1$ & B1 & C1 & D1 & 0.7 & 0.5 & 0.4 & 0.53 & 0.15 & 10.86 \\
\hline 2 & A1 & B2 & $\mathrm{C} 2$ & D2 & 0.4 & 0.6 & 0.5 & 0.50 & 0.10 & 13.98 \\
\hline 3 & A1 & B3 & C3 & D3 & 0.6 & 0.6 & 0.7 & 0.63 & 0.06 & 20.80 \\
\hline 4 & $\mathrm{~A} 2$ & B1 & $\mathrm{C} 2$ & D3 & 0.8 & 1 & 0.9 & 0.80 & 0.10 & 18.06 \\
\hline 5 & $\mathrm{~A} 2$ & B2 & C3 & $\mathrm{D} 1$ & 0.8 & 0.7 & 0.6 & 0.70 & 0.10 & 16.90 \\
\hline 6 & $\mathrm{~A} 2$ & B3 & $\mathrm{C} 1$ & D2 & 0.4 & 0.3 & 0.5 & 0.40 & 0.10 & 12.04 \\
\hline 7 & A3 & B1 & $\mathrm{C} 3$ & D2 & 1.5 & 1.4 & 1.6 & 1.50 & 0.10 & 23.52 \\
\hline 8 & A3 & B2 & $\mathrm{C} 1$ & D3 & 1.2 & 1.1 & 1.2 & 1.17 & 0.06 & 26.11 \\
\hline 9 & A3 & B3 & $\mathrm{C} 2$ & D1 & 0.8 & 1 & 1.1 & 0.97 & 0.15 & 16.03 \\
\hline
\end{tabular}

(Source: Original)

S.D-Standard Deviation

SNi-Signal to Noise ratio.

Table 4: $L 9\left(3^{4}\right)$ Orthogonal response table of water extraction method with conventional heating

\begin{tabular}{|c|c|c|c|c|c|}
\hline \multicolumn{7}{|c|}{ Response table for Signal to Noise ratio } \\
\hline Level & Number & Temperature(A) & $\begin{array}{c}\text { Water to plant } \\
\text { material ratio (B) }\end{array}$ & $\begin{array}{c}\text { Extraction } \\
\text { time(C) }\end{array}$ & $\begin{array}{c}\text { Solvent to } \\
\text { liquid ratio(D) }\end{array}$ \\
\hline 1 & $\mathrm{~K} 1 \mathrm{i}$ & 15.21 & 17.48 & 16.34 & 14.60 \\
\hline 2 & $\mathrm{~K} 2 \mathrm{i}$ & 18.58667 & 19.00 & 16.02 & 16.51333 \\
\hline 3 & $\mathrm{~K} 3 \mathrm{i}$ & 21.89 & 16.29 & 20.40667 & 21.66 \\
\hline$\Delta$ & & 6.67 & 2.71 & 4.07 & 5.14 \\
\hline Rank(R) & & 1 & 4 & 3 & 2 \\
\hline
\end{tabular}




\begin{tabular}{|c|c|c|c|c|c|c|c|c|c|}
\hline \multirow{2}{*}{ S.no } & \multirow{2}{*}{$\begin{array}{c}\text { Microwave } \\
\text { Power }\end{array}$} & \multirow{2}{*}{$\begin{array}{c}\text { Irradiation } \\
\text { Time }\end{array}$} & \multirow{2}{*}{$\begin{array}{l}\text { Solvent to } \\
\text { liquid ratio }\end{array}$} & \multicolumn{3}{|c|}{ Extraction Yield (\%) } & \multirow{2}{*}{ Mean } & \multirow{2}{*}{ S.D } & \multirow{2}{*}{$\mathrm{SNi}$} \\
\hline & & & & Trial1 & Trial2 & Trial 3 & & & \\
\hline 1 & A1 & B1 & C1 & 0.3 & 0.2 & 0.3 & 0.27 & 0.06 & 33.11 \\
\hline 2 & A1 & B2 & $\mathrm{C} 2$ & 0.6 & 0.6 & 0.7 & 0.63 & 0.06 & 31.01 \\
\hline 3 & A1 & B3 & C3 & 0.7 & 0.8 & 0.8 & 0.77 & 0.06 & 29.21 \\
\hline 4 & $\mathrm{~A} 2$ & B1 & $\mathrm{C} 2$ & 0.8 & 1 & 0.9 & 0.83 & 0.10 & 37.97 \\
\hline 5 & $\mathrm{~A} 2$ & B2 & C3 & 8.41 & 8.41 & 8.32 & 8.38 & 0.04 & 45.91 \\
\hline 6 & $\mathrm{~A} 2$ & B3 & C1 & 6.95 & 7.4 & 7.2 & 7.18 & 0.18 & 31.83 \\
\hline 7 & A3 & B1 & C3 & 7.15 & 7.25 & 7.15 & 7.18 & 0.05 & 43.66 \\
\hline 8 & A3 & B2 & C1 & 6.8 & 6.9 & 6.7 & 6.80 & 0.08 & 38.41 \\
\hline 9 & A3 & B3 & $\mathrm{C} 2$ & 7.11 & 6.8 & 7.1 & 7.00 & 0.14 & 33.75 \\
\hline
\end{tabular}

(Source: Original)

S.D-Standard Deviation

SNi-Signal to Noise ratio.

\begin{tabular}{|c|c|c|c|c|}
\hline \multicolumn{5}{|c|}{ Table : 6 L9 $\left(3^{4}\right)$ Orthogonal response table of MAE extraction method } \\
\hline \multicolumn{5}{|c|}{ Response Table for Signal to Noise ratio } \\
\hline Level & Number & Temperature (A) & Irradiation time (B) & Solvent to liquid ratio (C) \\
\hline 1 & $\mathrm{~K} 1 \mathrm{i}$ & 31.11 & 38.25 & 34.45 \\
\hline 2 & $\mathrm{~K} 2 \mathrm{i}$ & 34.24 & 38.44 & 34.24 \\
\hline 3 & $\mathrm{~K} 3 \mathrm{i}$ & 38.61 & 31.60 & 39.59 \\
\hline$\Delta$ & & 7.50 & 6.85 & 5.35 \\
\hline Rank (R) & & 1 & 2 & 3 \\
\hline
\end{tabular}

\begin{tabular}{|c|c|c|}
\hline \multicolumn{3}{|c|}{ Table: $\mathbf{7}$ Comparison of two extraction methods of polysaccharides } \\
Method & Water extraction & Microwave extraction \\
\hline Extraction temperature & $90^{\circ} \mathrm{C}$ & - \\
\hline Water to plant material ratio & $1: 1$ & - \\
\hline Extraction time & 1 hour $30 \mathrm{~min}$ & - \\
\hline Microwave Power & - & $200 \mathrm{~W}$ \\
\hline Irradiation time & - & $20 \mathrm{~min}$ \\
\hline Solvent to liquid ratio & $2: 1$ & $3: 1$ \\
\hline (Source: Original).
\end{tabular}

tion, heating was carried out using microwave oven where the material was kept in china dish. Small porcelain pieces were used to avoid pumping. Extractions were performed at different conditions using single factor experiments.

The factors that influenced MAE of polysaccharides extraction include microwave power, irradiation time and solvent to liquid ratio. The factors and their levels are given in Table 2.

\section{RESULTS}

\section{Results of water extraction method with conventional heating}

Based on the single factor experiments, the results of the orthogonal experiment is shown in Table 3, The results show that the extraction yield increased with the increase in temperature. Extraction yield was directly proportional to extraction time. When the solvent to water to plant material ratio reached at least 2:1 or above the extraction 
yield was the highest. No significant change in extraction yield was observed for solvent to liquid ratio above 1:2. From Table 3 and 4 the optimum conditions were determined by orthogonal test and extreme difference analysis $(\mathrm{R}=\max \mathrm{Ki}-\min \mathrm{Ki})$. According to the value $R\left(R_{A}=6.67>R_{D}>R_{C}>R_{B}\right)$, the influence of temperature on the extraction yield of polysaccharides among the four factors was the biggest. These factors were sequenced by their influence on extraction yield for $\mathrm{A}>\mathrm{D}>\mathrm{C}>\mathrm{B}$. The optimum extraction conditions were $\mathrm{A}_{3} \mathrm{~B}_{1} \mathrm{C}_{3} \mathrm{D}_{2}$, temperature $90^{\circ} \mathrm{C}$, water to plant material ratio $1: 1$, extraction time $1 \mathrm{hr} 30$ minutes and solvent to liquid to ratio $2: 1$, the extraction yield attained the optimum level.

\section{Results of MAE extraction method}

According to the single factor experiments of MAE method, the extraction yield was increased with increase in microwave power. Solvent liquid ratio 3:1 was the best ratio in single factor experiments. Based on the single factor experiments, the results of orthogonal experiment and extreme analysis were shown in Table 5 and 6. In Table 6, microwave power had the highest $R$ value (7.50), the effects of the variables on extraction yields followed the order: microwave power $>$ irradiation time $>$ solvent to liquid ratio. According to the experimental values, the optimal combinations were $\mathrm{A}_{2} \mathrm{~B}_{2} \mathrm{C}_{3}$, microwave power $200 \mathrm{~W}$, irradiation time $20 \mathrm{~min}$ and solvent-liquid ratio 3:1. The summary results of these two methods in optimal conditions are shown in Table 7. Extraction yield of microwave assisted method was higher than water extraction method with conventional heating.

\section{DISCUSSION}

Over the past decade, numerous studies have attempted to study extraction of polysaccharides and mucilage from several fruits. Huiping et al isolated polysaccharides by water extraction method by conventional heating with continuous stirring on a stir plate for $2 \mathrm{~h}$ at $100^{\circ} \mathrm{C}$ from wolfberry, cherry, kiwi and cranberry fruits. ${ }^{18}$ Hindustan et al isolated mucilage by water extraction method by boiling the fruit mixture for 30 minutes from Ficus fruit and formulated transdermal patches using the isolated mucilage. ${ }^{19}$ Jia et al extracted five soluble polysaccharides using water and other different solvents by the conventional heating at room temperature for 4 hours from cell wall material of rabbit blue berry fruits. The sequential treatments yielded a total $36.02 \%$ soluble polysaccharides of the dry cell wall material. ${ }^{20}$ Amina et al extracted polysaccharides by water extraction method by conventional heating at $80^{\circ} \mathrm{C}$ for $24 \mathrm{~h}$ and precipitation with
$70 \%$ (v/v) ethanol. ${ }^{21} \mathrm{Yu}$ et al extracted and optimized polysaccharides from Auricularia auricula fruiting bodies (AAFB) using response surface methodology (RSM). The Box-Behnken experimental results showed the optimum extraction conditions as a liquid-solid ratio of $38.77 \mathrm{~mL} / \mathrm{g}$, a temperature of $93.98^{\circ} \mathrm{C}$ and a time of $3.41 \mathrm{~h}$. Under these conditions, the maximal polysaccharide yield was $10.46 \mathrm{~g} / 100 \mathrm{~g} .{ }^{22}$

Shah (2010) et al optimized conventional and microwave assisted methods the extraction of mucilage from the fruits of Trichosenthes dioica plant. Microwave extraction at $320 \mathrm{~W}$ intensity and 20 min heating duration, 84.92\% increase in the yield of mucilage while $52.06 \%$ and $38.09 \%$ increase in the yield at $640 \mathrm{~W}$ for $5 \mathrm{~min}$ and $160 \mathrm{~W}$ for 40 min respectively were obtained under microwave irradiation when compared to $1 \mathrm{~h}$ conventional heating method. The products obtained by both the methods were of similar nature both physically and chemically. ${ }^{23}$ Brien (2010) et al extracted mucilage from the fruits of Lagenaria siceraria plant by conventional and microwave assisted methods. Microwave extraction at $320 \mathrm{~W}$ intensity and $20 \mathrm{~min}$ heating duration, $96.15 \%$ increase in the yield of mucilage while $93.95 \%$ and $91.20 \%$ increase in the yield at $160 \mathrm{~W}$ for $60 \mathrm{~min}$ and $480 \mathrm{~W}$ for $10 \mathrm{~min}$ respectively were obtained under microwave irradiation when compared to $1 \mathrm{~h}$ conventional heating method. ${ }^{24}$ Yonggang et al (2010) optimized the Microwave-assisted extraction of watersoluble polysaccharides from Piteguo fruit by Response surface methodology a central composite design was used to optimize microwave power (400-600 W), extraction time (5-10 $\mathrm{min})$ and ratio of water to material (30:1-50:1 mL/g) to obtain a high crude polysaccharides yield. The statistical analyses indicated that all of the three factors had significant effect on the extraction yield of crude polysaccharides $(p<0.001)$. The results showed that the extraction ratio of crude polysaccharides was up to $7.86 \%$ under the optimum extraction conditions as follows: microwave power $550 \mathrm{~W}$, extraction time $9 \mathrm{~min}$, water to material ratio $45 \mathrm{~mL} / \mathrm{g}$, which was consistent with the predicted models with the coefficients of determination $\left(\mathrm{R}^{2}\right)$ of $0.9809 .{ }^{25}$ Biren et al (2011) isolated mucilage from Ablmoschus esculentis fruits both by water extraction heating and microwave method. In water extraction, the fruit material blend in water was boiled for $1 \mathrm{~h}$ under reflux and with bumping. In microwave method the blend was subjected to microwave irradiation at $160 \mathrm{~W}$ intensity and $40 \mathrm{~min} .11 .55 \%$ increase in the yield of mucilage compared to the conventional heating method. The process parameters include microwave power, irradiation time as yield as independent variable. ${ }^{26}$ 
In recent years, extraction of polysaccharide from Psidium guajava L. fruit has been studied. Only hot water extraction from Psidium guajava $L$ fruit is reported so far. ${ }^{27} \mathrm{But}$ the comparative research on the two methods water extraction with conventional heating and Microwave assisted extraction of Psidium guajava L. fruit polysaccharides have not been reported until now. So this study is attempted to isolate polysaccharides from Psidium guajava L. fruit using hot water and microwave and compare these two methods by the orthogonal experiment. Comparison is shown in Table 7. The best method which has got significance to the research and application of polysaccharides is ascertained.

Water extraction with conventional heating is an easy method and will not destroy the molecules of polysaccharides; it will have elevated temperature and long extraction time. Dehong et al reported that polysaccharides are obtained from Psidium guajava L. fruits at $80^{\circ} \mathrm{C}$ for 3 hours. ${ }^{28}$ Mandal et al also reported about hot water extraction of polysaccharides from the same fruit. ${ }^{27}$ In our study, according to the results of the orthogonal experiment in Table 3, it was found that, the optimal conditions of water extraction were $90^{\circ} \mathrm{C}$ temperature, 1:1 water to plant material ratio, extraction time 1 hour 30 minutes, 2:1 solvent to liquid ratio, and the extraction yield was $1.17 \%$.

During microwave extraction, it is necessary to optimize the conditions. The results of the microwave orthogonal experiment were shown in Table 6, the optimal process conditions were microwave power $200 \mathrm{~W}$, irradiation time 20 min, solvent to liquid ratio $3: 1$. The results of the microwave extraction indicate that the highest extraction yield is $8.38 \%$ under optimal conditions (200 W, 20 min, 3:1 ratio). The results indicate that there is linear rise in the polysaccharide yield from 100-200 W. This enhancement is owing to the fact that rise in microwave power will improve the solubility of the sample for the improved extraction efficiency. ${ }^{29}$ The raise in microwave power increases dipole reactions which produces heat generation in the mixture as a result of power degeneration. After $200 \mathrm{~W}$, there is slight decrease in the yield of polysaccharide.

When comparing the process variable of the water extraction with conventional heating with that of the available literature on extraction of mucilage or polysaccharides from other fruits, it is understood that the temperature in conventional heating $70^{\circ} \mathrm{C}-90^{\circ} \mathrm{C}$ time 30 min-1 h 30 min would give proper result, and is supported by the reports of Huiping et al $\left(1 \mathrm{hr}\right.$ at $\left.100^{\circ} \mathrm{C}\right)$, Hindustan (30 minutes), Shah et al (1 h). In the same way, when comparing the process variable of the water extraction with conventional heating with that of the reported studies on extraction of mucilage or polysac- charides from other fruits, it is understood that the process variables generally adopted were microwave power and irradiation time. Only very few articles discussed variables such as water to plant material ratio, liquid to solvent ratio. The process variables provided maximum yield by the reported study by Shah et al $(320 \mathrm{~W}$ intensity and $20 \mathrm{~min})$, Biren et al (320 W intensity and $20 \mathrm{~min}$ ) supports the selection of the process variables of the present study as microwave power in the range of 100-300W and irradiation time 10-20 min.

\section{CONCLUSION}

In this study, water extraction with conventional heating and microwave assisted extraction methods of polysaccharides in Psidium guajava L. fruits were compared. By the result of the single factor method and orthogonal experiments, the optimal extracting conditions were selected and then the best extraction method was ascertained. Extraction time of microwave extraction time is too short and the extraction yield is higher. So by comparing the data and condition of two methods, it is concluded that microwave method is the better method. Further prospects for the experiment can be carried out by ultrasonic extraction of polysaccharides from Psidium guajava $\mathrm{L}$ fruit and even best of these three methods can be ascertained.

\section{ACKNOWLEDGEMENTS}

The authors are thankful to Dr. T. K. Ravi, Principal, College of Pharmacy, Sri Ramakrishna Institute of Paramedical Sciences and S. N. R. Sons Charitable Trust for providing adequate facilities to carry out this research work.

\section{CONFLICT OF INTEREST}

The authors do not have any conflict of interest.

\section{REFERENCES}

1. Hardial S and Manhas R K. Guava: Nature's Gift to Mankind. Journal of Biosphere. 2013;2(1):72-3.

2. Smith R M and Siwatibau S. Sesquiterpene hydrocarbons of Fijian guavas. Phytochemistry 1975;14(9):2013-5. http://dx.doi.org/10.1016/00319422(75)83115-3.

3. Macleod AJ and Troconis NG. Volatile flavour components of guava. Phytochemistry. 1975;21(6):1339-42. http://dx.doi.org/10.1016/00319422(82)80138-6.

4. Lutz R, Aserin A, Wicker L and Garti N. Structure and physical properties of pectins with block-wise distribution of carboxylic acid groups. Food Hydrocolloid. 2009;23(3):786-94. http://dx.doi.org/10.1016/j.foodhyd.2008.04.009.

5. Al-Sheraji SH, Ismail A, Manap MY, Mustafa S, Yusof RM, et al. Purification, characterization and antioxidant activity of polysaccharides extracted from the fibrous pulp of Mangifera pajang fruits. LWT-Food Science and Technology. 2012;48:291-6. http://dx.doi.org/10.1016/j.Iwt.2012.04.002. 
6. Bao Y, Yueming J Mouming Z, Feng C, Rui W, Yulong C, et al. Structure characterization of polysaccharide purified from longan (Dimocarpus longan Lour.) fruit pericarp, Food Chemistry. 2009;115(2):609-14. http://dx.doi. org/10.1016/j.foodchem.2008.12.082.

7. Jinwei L, Lianzhong A, Qin Y, Yuanfa L and Liang S. Isolation and structural characterization of a polysaccharide from fruits of Zizyphus jujuba cv. Junzao. International Journal of Biological Macromolecules. 2013;55:83-7. http://dx.doi.org/10.1016/j.ijbiomac.2012.12.017 ; PMid:23262389.

8. Nisarg C P, Tanvi PP, Vaishali NS and Ashok NM. Isolation of mucilage from Cydonia vulgaris pers. Seeds; and its evaluation as A tablet binder. International Journal of Pharmacy and Pharmaceutical Sciences. 2011;3(4):351-5.

9. Stone AX, Bing S and Yunru L. Honeysuckle and other resources of medicinal, chemical and pharmacological research progress. Chinese Pharmaceutical Journal. 1999;34:724-7.

10. Hong-chang L. Wang body phase study of polysaccharide extraction process. Purple Salvia Taishan Medical College. 2007;28:251-2.

11. Xiaowei H. Research progress of polysaccharides extraction of medicinal plants. 2010.

12. Yansui $H$, Wen-wang $L$ and Jing $C$. Such as technology and mathematical simulation chrysanthemum Ultrasonic Extraction. Chinese Journal of Hospital Pharmacy. 2010;30:188-90.

13. Yan-yan X. Extraction methods and processes of plant polysaccharides. Fujian Aquaculture. 2006;3:33-6.

14. Shayeeb $A B$ and Rongen $S$. Extraction and characterization of pectin from extraction and characterization of pectin from guava fruit peel. International Journal of Research in Engineering \& Advanced Technology. 2014;2(3).

15. Varshosaz J, Tavakoli N, Minayian M and Rahdari N, Applying the Taguchi Design for Optimized Formulation of Sustained Release Gliclazide Chitosan Beads: An in vitro/in vivo Study. AAPS Pharm Sci Tech. 2009;10(1):158. http://dx.doi. org/10.1208/s12249-009-9191-8; PMid:19205888 PMCid:PMC2663681.

16. Mihaela VG, Lăcrămioara P, GA Briel Ş, Minodora L, Dumitru L, et al. Optimization of the pharmaceutical products and process design applying taguchi quality engineering principles. Farmacia. 2011;59(3):321-8.

17. Musonda E K and Chen Y. Optimization of Cutting parameters when Hard Turning Hardened $42 \mathrm{CrMo} 4$ steel using the Taguchi method. International Journal of Advanced Research. 2014;2(8):911-23.

\section{PICTORIAL ABSTRACT}

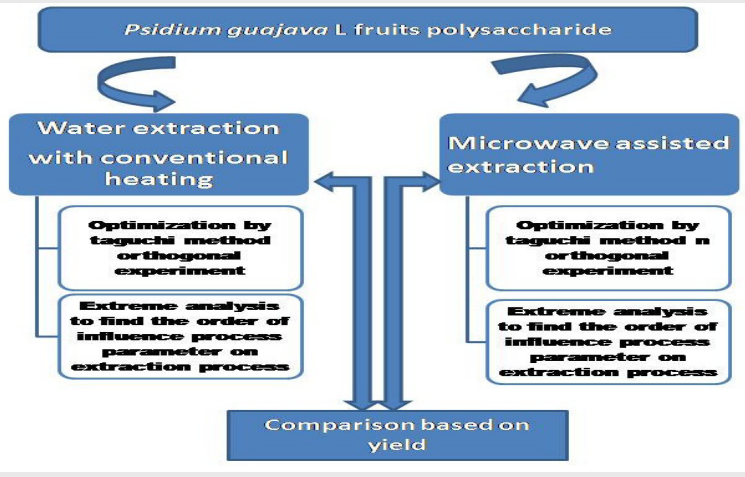

18. Huiping F, Mazza G and Liao X. Purification, composition and antioxidant activity of polysaccharides from wolfberry, cherry, kiwi and cranberry fruits, Croat. J Food Sci Technol. 2010;2(1):9-17.

19. Hindustan AA, Chitta SK, Anil Kumar B and Amarnath. Permeation studies of Diclofenac sodium from Ficus carica fruit mucilage matrices for transdermal delivery. International Journal of Pharm Tech Research. 2010;2(2):1013-7.

20. Jia D, Zeng-JS, Xian-ZL and Hui ML. Soluble polysaccharides isolation and characterization from Rabbiteye bluberry (Vaccinium ashel) fruits. Bioresources. 2013;8(1):405-19.

21. Amina C, Saoudi A and Alain. Extraction, fractionation and characterization of water-soluble polysaccharide fractions from myrtle (Myrtus communis L.) fruit. Food Hydrocolloids. 2014;35:733-9. http://dx.doi.org/10.1016/j.foodhyd. 2013.08.001.

22. Yu-LH, Jie G, Yan-YY and Han-QC. Extraction optimization by response surface methodology of mucilage polysaccharide from the peel of Opuntia dillenii haw. fruits and their physicochemical properties. Food Sci Technol. 2015;35(3).

23. Shah BN, Seth AK and Nayak BS. Microwave assisted isolation of mucilage from the Trichosanthes dioica fruit International Journal of Pharmaceutical Sciences and Research . 2010;1(5):68-72.

24. Biren. NS, Avinash KS and Bhavesh SN. Microwave assisted isolation of mucilage from the fruits of Lagenaria Siceraria. Der Pharmacia Lettre. 2010;2(2):202-5.

25. Biren NS and Avinash KS. Microwave assisted isolation of mucilage from the fruits of Abelmoschus esculentus. Hygeia J D Med. 2011;3(1):54-7.

26. Yonggang W, Feifan L, Xiaofeng L and Mingjun Y. Optimization of MicrowaveAssisted Extraction of Water-Soluble Polysaccharides from Piteguo Fruit by Response Surface Methodology. Food Science and Technology Research. 2014;20(4):755-64. http://dx.doi.org/10.3136/fstr.20.755.

27. Mandal S, Sarkar R, Patra P, Nandan CK, et al. Structural studies of a heteropolysaccharide (PS-I) isolated from hot water extract of fruits of Psidium guajava (Guava). Carbohydrate Research. 2009;344(11):1365-70. http://dx.doi.org/10.1016/j.carres.2009.05.009 ; PMid:19500779.

28. Dehong $\mathrm{H}$, Dezhi Z, Bing $\mathrm{H}, \mathrm{Pan} \mathrm{Y}$ and Chunyan $\mathrm{Y}$. Structural characterization and DPPH• radical scavenging activity of a polysaccharide from Guara fruits. Carbohydrate Polymers. 2014;103(1):143-7.

29. Bourtoom T, Chinnan MS,.Jantawat $P$, Sanguandeekul R, Recovery and characterization of proteins precipitated from surimi wash water. LWTFoodscience Technology. 2009;42(2):599-605. http://dx.doi.org/10.1016/j. Iwt.2008.09.001.

\section{SUMMARY}

- Extraction of polysaccharides from Psidium guajava $L$ fruits was carried out by water extraction with conventional heating and microwave assisted method.

- Optimization of polysaccharide extraction method was performed by single factor experiments and orthogonal experiment. Then extreme analysis was performed to know the order of parameters in which they influence the extraction process.

- Microwave assisted method was selected as a better method among these two extraction methods.

- The optimum extraction parameters in water extraction with conventional heating were identified as temperature $90^{\circ} \mathrm{C}$, water to plant material ratio $1: 1$, extraction time $1 \mathrm{hr} 30 \mathrm{~min}$ and solvent to liquid to ratio $2: 1$, the optimal process conditions in Microwave assisted extraction were microwave power $200 \mathrm{~W}$, irradiation time $20 \mathrm{~min}$, solvent to liquid ratio $3: 1$. Highest yield of polysaccharide was obtained in the optimal extraction conditions for both the extraction methods

- Yield is higher in the microwave assisted extraction method than water extraction with conventional heating method. 